\title{
Entanglements: Cultural Borders in Visions of European Unification
}

\section{MATS ANDR ÈN}

Department of Literature, Religion, and History of Ideas, University of Gothenburg, Box 200, SE-405 30 Gothenburg, Sweden. Email: mats.andren@lir.gu.se

This article elaborates upon the idea of cultural borders from the perspective of European unification before EU-integration. It addresses discussions on how to manage or even transcend religious and linguistic borders, from William Penn, Novalis and Conrad Friedrich Schmidt-Phiseldeck, to Johann Caspar Bluntschli and Richard Coudenhove-Kalergi. The historical contexts are nationalism and Europeanization. These are further illuminated by the use of constructivist theory and the concept of a 'stagist theory' from Dipesh Chakrabarty and Roberto Dainotto which legitimizes the domination of some nations over others.

\section{Introduction}

The idea of European unification has always included transcending some borders and emphasizing others. Discussion of territorial borders has long held a privileged position in proposals for a common economic market and a customs union governed by common political bodies. However, visions of European unification have also reflected on how to go beyond cultural borders. My objective is to comment on such visions pre-dating the beginning of actual European integration after the Second World War. More precisely I will look at the means, and intellectual devices, with which visionaries in the nineteenth and early twentieth centuries proposed to reach beyond these cultural borders. I am particularly interested in religion and language as marking cultural borders.

\section{Nation, Language and Religion}

Certain key notions for our time, as well as for the past, include nation and nationalism, when it comes to the cultural borders of Europe. Nationalist sentiments are proclaimed with flags, national holidays, and manifest declarations of national values, but they can also be found in our daily lives. Michael Billig has highlighted how 
nationalism has become deeply embedded in the minds of citizens. When this happens, the nation comes more likely to be seen as a social inevitability, a kind of natural order beyond historical contexts (Billig 1995). Clearly, nationalism is something both widespread and deeply intertwined with the history of modern Europe, and languages and religions are crucial elements for the concept of 'nation' and the feeling of belonging to a national community.

With this in mind, we should recall that linguistic differences have historically been seen as more recent markers of cultural borders, especially so in comparison with religious divides, which had already started to play a significant role in the Middle Ages. Some scholars argue that language is the most important indicator of ethnic communities and that it plays the most important role in the creation of the nation state. Regardless of whether this is true, given that language did not play a decisive role in defining borders prior to the nation state era it is remarkable how it has come to occupy such a place of prestige in nationalism and the nation state. In fact, language did not play a substantial role until relatively recently. A prince did not care which language the peasants spoke amongst themselves, but he had a need to communicate with his equals. Latin was the lingua franca of the elites until French took over. It was only after the invention of the printing press and the Reformation that publishing in other vernaculars began to take hold. It is just two centuries ago that the novel idea of linguistically homogeneous nation states began to gain traction. Benedict Andersson has stressed that it was the impact of the codification of vernaculars and the philological work done in the eighteenth and nineteenth centuries which 'created, and gradually spread, the conviction that languages (in Europa at least) were, so to speak, the personal property of quite specific groups, imagined as communities,' entitled to their autonomy (Anderson 1991 [1983], 84).

The European states eventually imposed national languages, and the long struggle then began to enforce political borders that aligned with specific languages and to impose linguistic borders that aligned with political communities; sharp linguistic borders are thus a modern construction. However, they never were perfectly enforced. The subordinated peoples of the German, Habsburg and Russian Empires struggled for linguistic rights, as did linguistic minorities in France and Spain, but also the Flemish majority of Belgium. Some states maintained more than one official language and all European states had, and continue to have, linguistic minorities within their borders.

In the nineteenth and twentieth centuries, the cultural borders of national identities became important in state-building and in mobilizing resources. A map by the Prussian officer and cartographer Johann Friedrich von Stülpnagel illustrates the entanglement of political and cultural borders. Stülpnagel drew several maps of Europe over a number of decades starting from the late 1820s, including some intended for schools. The map from 1871 was an adaptation of an original from 1841. Outlining the political borders of slightly fewer than 20 European states, including the Ottoman Empire, it depicts Germany as one single state, as it was drawn in the same year that Bismarck brought about the unification of the country, and it does the same thing with the newly united Italy. 
Interestingly, two appendix maps accompany this political map. One lists the main religions of Europe, including Catholicism, Orthodox Christianity, Protestantism, Judaism and Islam. Europe is conceived geographically as comprising all of the Balkans and so also those parts that belonged to the Ottoman Empire, and Islam is pictured as one of the continent's religions. Yet, while Western Christendom is divided between the Catholic and Protestant churches, neither Orthodox Christendom nor Islam are divided into different churches; apparently their varieties are not recognized.

The other map divides Europe into 25 nationalities, detailing Gaelic peoples, Bretons and Basques in Western Europe; Finns, Estonians, Latvians and Lithuanians in Russia; and Czechs, Poles and Serbs in Central Europe. The supplementary maps thus show the linguistic and religious diversity of Europe masked by the territorial borders outlined on the political map. The Habsburg Empire, for instance, is shown as using several languages, certain states have linguistic minorities, and some have more than one religion within their borders (Stülpnagel and Bär 1871).

\section{Early Nineteenth Century Visionaries and Europeanization}

The entanglements of cultural borders and Europeanization have been numerous and we should remember that trade, communication and travel, cultural exchange and the spread of ideas and values took place long before the formation of the EU. The most obvious example is how cultural borders are addressed when it comes to ideas of European unity. In the beginning of the nineteenth century the European idea often started from the notion that Europe would be better off if it shared one religion. Even though Novalis fantasized about the communal church of the Middle Ages in 1799, he had neither Catholicism nor Protestantism in mind for the future, but something that could integrate the old with the new. His vision was of a new unified church that could overcome not only the religious divides, but also act as a cornerstone for the establishment of European unity (Novalis 1996; Svennungsson 2014). Napoleon also talked of unity with the intention of transcending borders. For some time he was the leader of a European-wide empire which, he argued, had in fact only one religion. In envisioning a united Europe he was radical; his Europe comprised only one people and consisted of a single nation with a singular tradition (Thompson 1994). The Danish official Conrad Friedrich Schmidt-Phiseldeck, who around 1820 launched extensive pleas for a European federation, may exemplify the claims of a shared Christian culture that could transcend cultural borders. He repeated the claim that all Europeans belonged to one single nation; no matter whether they were French, German, Italian or Spanish, they were all entitled to be European citizens (Schmidt-Phiseldeck 1821, 270). And all were Christians, regardless of whether they were Protestant or Catholic:

In Christian Europe the main components of the political physiognomy, the basic characteristics of mutual relationships of people and citizens, the common forms of culture and ways of life, are everywhere the same. (Schmidt-Phiseldeck 1821, 304) 
Such radical views soon became the exception. Instead, a kind of realist vision of European cooperation entered the scene, one that accepted many cultural differences and national traditions. The question then became how far political unity could be taken with the cultural borders as a prerequisite. In pleas for a European federation both Catholics and Protestants downplayed religion as essential. This is not surprising when it comes to proposals written by Germans after the German unification as the latter had also meant overcoming the long historical divide between Catholics and Protestants in the German-speaking territories. However, the same willingness to go beyond the historical differences within Western Christianity featured throughout the discourse on European unification. The proposals to merge European nations with Christianity as a unifying factor excluded those parts of geographical Europe occupied by the Islamic Ottoman Empire. Orthodox Christendom, especially in its Russian guise, likewise was excluded from the discussion on European unity. Often, Russia was not seen as being part of European civilization but rather as a threat to the continent's individualism, its freedoms and ways of life.

With respect to linguistic borders the entanglement became more complex. Which language should the communal institutions use? William Penn (1693) proposed a European Parliament where the sessions 'must be held in Latin or French: the first would be very well for the Civilians, but the last most easie for Men of Quality.' French was long seen as the first choice, but things got more complicated when ideas promoting the rights of citizens began to circulate, insisting that all governance ought to derive its legitimacy from the people it represented. In 1814, Karl Krause wanted all treatises, laws and decisions made by a European federation to be ratified in all its languages. However, no strong objection to the use of French in federal bodies was voiced. Thanks to the proliferation of French and the greater ambitions to learn foreign languages among many of the European nations, it was argued in 1821 in the era's most ambitious proposal for a federation that linguistic obstacles would no longer hinder the formation of a European federation (Penn 1693; Krause 1899; Schmidt-Phiseldeck 1821).

The new more visionary concept of Europe emerging at the turn of the nineteenth century also included the aspect of European dominance. The term Europeanization dates back to the days when it implied how the main nations of Europe transformed the culture or civilizations of other regions within the continent itself or in their colonies in other parts of the world. It was already in use in Germany by 1795 when August Ludwig Schlözer, a Göttingen scholar who had specialized in Russian history, argued the benefit of German settlements among the Magyar population in Siebenbürgen, present-day Transylvania. In Schlözer's narrative, German monarchs had supported the Hungarian rulers in first opposing the Tatars, and later helping them to free their country from the yoke of the Ottoman Empire, thus creating a European nation. Further Immigration of Germans to Siebenbürgen would imbue the Magyar natives with more of European culture. Thus, the Germans contributed to European culture by importing their own culture. In this way, they played a vital role in the Europeanization of the Magyars (Schlözer 1795, VII, 177, 181, 191). 
The Germans were not the only agents of Europeanization, which soon included other continents as well. This had nothing to do with the opinions of those outside of Europe. They may appreciate it or not, as one writer stated, but they were Europeanized as the growing power of Europeans turned them into colonial subjects. Other writers concluded that just as European culture had made its way into parts of Russia and the Ottoman Empire, so Europeanization spread among the 'barbarians' in Africa and Asia. (Göttingisches Taschenbuch 1802, 83-85, Herrmann and Heeren 1822, 400). English publications speculated in a similar way that India would be a valuable part of the British Commonwealth Empire and thereby part of the European civilization.

Clearly, Europeanization implied that the margins were the pupils to the leading nations, especially to the English, German and French teachers. Thus, Europeanization included what Dipesh Chakrabarty dubbed as the 'stagist theory' of history. This entails that some countries lay claim to being at the origin of things, which then qualifies them to assume a leading role vis-à-vis other countries or continents. While Chakrabarty discusses the impact that European colonialism had on India, Roberto M. Dainotto reminds us that a similar mindset was already at work within Europe. An example of this is how the French Enlightenment philosophers viewed Italy and Spain as backwards when compared with France. Montesquieu argued that these countries had been leaders in Antiquity, but modern Europe had originated in France, and had progressed at such a rate that the more slowly moving Southern Europeans could not keep up (Chakrabarty 2008 [2000], 7-9; Dainotto 2007).

\section{Linguistic Nationalism and European Bodies}

The growth of linguistic nationalism challenged the predominance of French. After the Germans defeated France in the War of 1870, there was some discussion, underpinned by the peace movement, of a European federation. Victor Hugo (1898 [1870]) had long been in favor of such a federation as the best way to avoid warfare on the continent. Yet even he considered it unthinkable to have anything but French as the official language of the federation; if the European Parliament was to speak German, Europe would be regressing three centuries: French it must be!

Others suggested a multilingual solution. The Swiss jurist Johann Caspar Bluntschli's plan for a federation comprised 15 states - including almost all the European states. Not surprisingly, he suggested English, French and German as communal working languages for the European bodies he envisaged.

For such an organization, it is possible to overcome the language problem. On the present level of education, most educated men do have apart from their mother tongue a knowledge of one or two foreign languages of importance that makes it possible for them to understand published works and a speech. Indeed, no one should be denied to talk in his mother tongue. However, when the speakers want to make themselves understood by all or by the majority, they will have to speak French or English or German. In contemporary Europe, these three national languages are in 
any case the most widespread and almost every educated man knows at least one of them. In exceptional cases when a senator can only speak in his mother tongue it must be provided for that his speech be interpreted into one of these common languages. This is how things have long proceeded in Switzerland, at international conferences and associations. (Bluntschli 1879, 304)

The challenge is this: if language is one of the main, or even the main, indicator of the nation, how would it be possible to set up communal bodies comprising several countries? Bluntschli argues that the parties would have to agree that certain languages should be used and/or that the proper languages of the participants should be used with the assistance of translation/interpretation. Such agreements became even more reasonable after the fundamental changes in Europe following the Great War. The 1920s saw a discursive turn in European cooperation which already hinted at the integration happening after the Second World War.

\section{A New Europe Emerges after the Great War}

Following the Great War, once the gunpowder had dispersed, a new map of political borders took shape. The idea of independent nation states resonated within Europe and a number of new states emerged with the dissolution of the Austrian, German and Ottoman Empires. If a population identified itself as a nation with a language, history and traditions of its own, if it was large enough to carry on by itself, and if it was concentrated in a certain area, then the demands for independence did not seem so farfetched. This was when the long-term development of Europe began to shift to a continuously increasing number of nation states, and this endures even today, when we have some 50 European states. Thus, the new Europe had emerged. This was also when the mindset in Europe's intellectual history began to change. From the nineteenth century, it was clear that Europeans consisted of many cultures in demand of national rights. With the growing number of official languages any proposal for cooperation would now need to take into account the new status of many vernacular languages. Overall, awareness of the new borders was an important characteristic of the new mindset.

The British journalist Stephen Graham lamented in 1922 that these newly drawn borders posed drawbacks for the traveler, with the amount of time it took to get passports and visa, the costs of exchanging currency, and the distress at the borders when local officials only spoke the national language (Graham 1922). He was not the only one to find disadvantages to the new era. Manifold voices identified the new borders as hindrances to trade as communications became more difficult and each state imposed its own tariffs for goods. Economists blamed the borders for causing economic decline. Others saw the divisions as the main reason behind Europe's global decline, challenged as it was by both American and Asians powers. Some even talked of the waning of European civilization, and the word 'crisis' was on everybody's lips. The notion of a European crisis contributed to the discourse on European unification, offering a strong argument for the need to stick together; internal strife had 
weakened all of Europe, and continuing divisions would mean that Europe's downward spiral would only accelerate, with the US and Japan overtaking it on all fronts. Initiatives arguing for unification thus gathered new energy.

With the new nation-states in place and with the principle of national sovereignty generally accepted, we might expect the drafts for European unification to pay significant attention to the language issue. Surprisingly, this was not the case. A vast number of publications from the Interbellum deal with European crisis and decline, with the need to establish a European federation and proposals for how to bring this about. The array of nationalities of the authors of such publications, the references between them and their numerous translations bear witness to a truly European discourse. However, the linguistic issue does not occupy much space in this, and religion even less.

For the leader of the Pan-European movement in the interbellum, CoudenhoveKalergi, religion was not a very big issue. The division of the Reformation formed the backdrop to European culture, but Protestantism had led the way to modern Europe and was only one aspect of a shared European culture. Europe was Christian, no matter if Catholic or Protestant. Coudenhove-Kalergi left out Orthodox Christianity in both Southeast Europe and Russia. Regarding the language issue of the proposed European bodies, he was leaning towards either French, German or English, with the alternative of using all three. He raised another alternative, typical for the interwar period when popularity peaked for Ido, Esperanto and Interlingua, of using an artificial language that would be neutral for all nationalities involved. Coudenhove-Kalergi was not the one to go deeper into possible problems for the European bodies; if only all parts saw the necessity of a federation and were willing to cooperate then such practical obstacles would be of minor significance. However, he did mention that the federative institutions might include people with altogether 40 spoken languages, and added that the issue of language importantly touched upon matters of prestige. He argued that the states of Europe normally counted more than one language within their borders and that a general acceptance of multilingualism would avoid many conflicts. They should follow the models of Switzerland, with regional autonomy, Estonia, with cultural autonomy, and Finland, with bilingualism. Moreover, Europeans should learn more than one language in order to be more open-minded and to go beyond one's own cultural frame.

In the end, Coudenhove-Kalergi conceived Europe as one culture and as one single nation, with a shared history, a common religious conception, and with languages belonging to the same Indo-Germanic family. Clearly, he envisioned European unification as transcending religious and linguistic borders. He did, however, stress the cultural borders between Europe and the rest of the world (Coudenhove-Kalergi 1934, 188ff, 279f, 292f).

\section{To Conclude}

The notion of Europe as a divided place, in decline and in crisis was essential to the mindset which contributed to European integration post-1945. The necessity 
of cooperation was proclaimed in a cultural landscape where borders and national identities were considered to be fundamental. It was from here that the concept of postwar European integration gained momentum, as a way to counteract decline and crisis while keeping to the nation states.

It is often recalled that the founding fathers of European integration were Catholics, but one should also bear in mind that from the very beginning the community had leaders and comprised substantial populations that were Protestant. The linguistic issues regarding the European bodies were dealt with much in line with Bluntschli's ideas, using (mainly) French and German as working languages for the officials (later complemented by English), with a rigorous use of simultaneous interpreting in meetings, especially of politicians, and in translating all documents into every official language of the community.

Although the language question has continued to be a topic of discussion, it is remarkable how successful the EU has been in terms of its language policy and its extensive use of translation and interpreting. Still, in contemporary Europe we can see a new trend towards cultural borders fueled by fear. Agitators of hard, fixed borders and exclusion are not afraid to make themselves heard. It is not so much language as religion that is in focus here, particularly Islam and non-European migrants.

Based on the ideas of European integration before the reality of EU-integration, we can see a desire to accommodate both linguistic and religious diversity. However, the emphasis on cultural borders vis-à-vis the world outside Europe persists. The choice we face today is whether to approach cultural borders with an inclusive mind, or to see them as an excuse for exclusion, even expulsion. We turn to cultural borders in order to answer the question of what kind of European integration we hope to have.

\section{References}

Anderson B (1991 [1983]) Imagined Communities. London: Verso.

Billig M (1995) Banal Nationalism. London: Sage Publications.

Bluntschli JC (1879) Die Organisations der Europäischen Statenvereins. In Gesammelte kleine Schriften II. Nördlingen: Verlag der C.H. Beck'schen Buchhandlung.

Chakrabarty D (2008 [2000]) Provincializing Europe: Postcolonial Thought and Historical Difference. Princeton: Princeton University Press.

Coudenhove-Kalergi RN (1934) Europa Erwacht! Zürich: Paneuropa-Verlag.

Dainotto RM (2007) Europe (in Theory). Durham: Duke University Press.

Göttingisches Taschenbuch zum Nuzsen und Vergnügen für das Jahr 1802 (1802) Göttingen: Heinrich Dieterich.

Graham S (1922) Europe - Whither Bound? (Que Vadis Europa?): Being Letters of Travel from the Capitals of Europe in the year 1921. London: Thornton Butterworth.

Herrmann A and Heeren L (1822) Handbuch des Geschichte des Europäischen Staatensystems und seiner Colonien. Göttingen: Johann Friedrich Römer.

Hugo V (1898 [1870]) Letter to M. D'Alton Shee. In Meurice P (ed.), The Letters of Victor Hugo: From Exile, and after the Fall of the Empire. Boston: Houghton, Mifflin and Company. 
Novalis (1996) Die Christenheit oder Europa. In Die Christenheit oder Europa und andere philosophische Schriften. Köln: Könemann.

Krause K (1899) Entwurf eines europäischen Staatenbundes, als Grundlage des allgemeinen Friedens und als Rechtlichen Mittels gegen jeden Angriff wider die innere und äussere Freiheit Europas. In Monatshefte der Comenius-Gesellschaft. Berlin: Keller.

Penn W (1693) An Essay towards the Present and Future Peace of Europe by the Establishment of an European Dyet, Parliament, or Estates. London.

Schlözer AL (1795) Geschichte der Deutschen in Siebenbürgen. Göttingen: Vandenhok \& Ruprechtschem Verlage.

Schmidt-Phiseldeck CF (1821) Der Europäische Bund. Kopenhagen: Friedrich Brummer.

Stülpnagel F and Bär JC (1871) Karte von Europa und den Mittelländischen Meer. Gothia: A. Petermann.

Svennungsson J (2014) Christian Europe: borders and boundaries of a mythological conception. In Lindberg S, Ojakangas M and Prozorov S (eds), Europe beyond Universalism and Particularism. Houndmills: Palgrave Macmillan.

Thompson MP (1994) Ideas of Europe during the French Revolution and the Napoleonic Wars. Journal of the History of Ideas $\mathbf{5 5}, 1$.

\section{About the Author}

Mats Andrén has been Professor (since 2005) in the History of Ideas and Science at the University of Gothenburg, and is a former director and steering group chairman for the Centre for European Research at the same university (CERGU, www.cergu.gu.se//). He was pro-dean of the Faculty of Arts 2011-2016. He teaches and supervises in European Studies and has published widely on European intellectual history. Among his recent books are Cultural Borders of Europe: Narratives, Concepts and Practices in the Present and in the Past (Berghahn 2017, edited with Lindkvist, Söhrman and Vajta) and Nuclear Waste Management and Legitimacy: Responsibility and Nihilism (Routledge 2012). He was previously guest editor of the Focus on European Nihilism, in European Review 22 (2014, with Jon Wittrock), and guest editor of 'Transnationalism in the 1950's Europe, Ideas, Debates and Politics', in History of European Ideas 2020, 46(1) (with Ettore Costa). 